\title{
Education Officer for Galapagos
}

$\mathrm{N}$ officer to organise and co-ordinate conservation education in the
Galapagos Islands has been appointed by the Ecuadorian Minister of Education, Dr Ciceron Robles Velasquez, who is President of the Unesco National Commission of Ecuador. He is Señor Lucio Saltos Gomez, who for the last four years has been Supervisor of Education in Galapagos, developing education programmes in association with the Charles Darwin Research Station. The new post will enable him to extend the teaching of conservation biology in the schools and develop programmes for adult education and exhibitions, and also training courses for guides in the national park.

The Ecuadorian government has also sent two forestry officials (national parks come under the Department of Forestry) to Galapagos to lay the foundation of the administration of the national park.

The problem that goats present is well shown on the island of

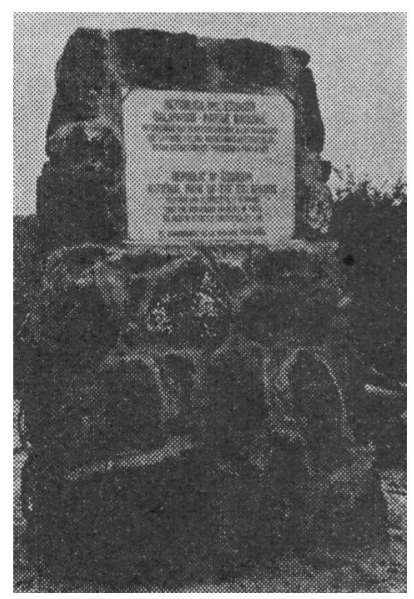

A Reminder-see below Pinta (Abingdon). One male and two female animals were put down on the island in 1959. By August 1968 it was estimated that there were between three and five thousand on the island. The vegetation of the lower slopes had suffered extensively, with many species scarce or absent. Unfortunately, there is evidence that goats are still being put down on islands.

A major eruption of the volcano on Fernandina island in June, of which an excellent account by Dr P. Colinvaux appeared in the September issue of Animals, caused part of the crater floor to collapse. What is not known is what has happened to the large flock of Galapagos pintail, which occupied the crater lake. The last census of flamingos in the islands, however, showed numbers to be well up with 550 birds.

\section{Reminder to Visitors}

Plaques set in pillars of lava blocks, like this one illustrated, are being erected near the landing places on all the islands in the park as reminders to all that the wildlife is protected. The inscription in Spanish and English reads:

Republic of Ecuador

National Park of the Galapagos

Visitors are respectfully reminded

that the indigenous wildlife of these

islands is strictly protected by law. 